Studia Slavica Savariensia 2016. 1-2. 362-369

DOI: $10.17668 /$ SSS.2016.1-2.362

Ráduly Zsuzsanna

(Budapest, Magyarország)

\title{
AZ EPONIMÁK FONOLÓGIAI ÉS MORFOLÓGIAI ADAPTÁCIÓJA A MAGYAR, A LENGYEL ÉS A HORVÁT NYELVBEN
}

\begin{abstract}
The subject of the present article is the phonological and morphological adaptation of eponyms in the Hungarian, Polish and Croatian languages. Eponyms - words and expressions formed through the appelativization of proper names - number over a thousand in all three languages.

Though phonological adaptation shows numerous similarities in the three languages, the individual solutions vary due to the different systems of phonemes. It is quite common for writing to follow pronunciation.

Similarities among the languages abound in the area of morphological adaptation as well. Similar suffixes - derived mostly from Latin - are common, especially for words referring to the same concepts.

Keywords: eponyms, phonological and morphological adaptation, Hungarian language, Polish language, Croatian language
\end{abstract}

Az eponima terminus (lengyel eponim, horvát eponim) a görög nyelvből származik, az epōnymos/epōnumos kéttagú kifejezésből, ami az epi és onoma összetételéböl keletkezett, jelentése 'névadó'. A szó a nemzetközi szókincs körébe tartozik, az egyes európai nyelvek különböző korszakokban vették át saját nyelvükbe. Kezdetben az eponymosok (eponimák) csoportját pontosan meghatározták. Az ókorban az eponymosok (eponimák) olyan istenek, hősök és személyek voltak, akikröl városokat, törzseket, vagy különbözö objektumokat neveztek el. Körükbe soroljuk az ókori tisztségviselőket is, így Athénban az arkhónokat, Rómában a konzulokat, Spártában pedig az ephoroszokat. Az eponima terminust a különböző nyelvekben elsősorban ebben az elsődleges jelentésben használták a humán tudományokban, leginkább a történelemben és az antropológiában.

A szó jelentése az idők során kibővült, fokozatosan nyelvészeti terminussá is vált, a nemzetközi szakirodalomban is egyre gyakrabban találkozunk vele. Kezdetben olyan tulajdonnevekre vonatkozott, amelyekből új tulajdonnevek keletkeztek. Pl. Amerigo Vespucci nevéből Amerika, Simon Bolivar nevéből Bolivia, Lord Baltimore nevéből Baltimore, Romulus nevéből Róma vagy Pallasz Athéné nevéből Athén. Ma már azokat a szavakat is ezzel a terminussal 
illetjük, amelyek tulajdonnevekböl - leggyakrabban személynevekből és földrajzi nevekböl - köznevesültek.

Ez a közszóvá válás jelenség a nyelvfejlődés egyes szakaszaiban minden nyelvben megfigyelhetö. Az ily módon alkotott szavak és kifejezések legtöbbször nem korlátozódnak csupán egyetlen nyelv szókincsére, hanem kisebb vagy nagyobb mértékben eltérö formában megtalálhatók az ún. nemzetközi szókincsben is. Az eltérések az egyes nyelvekbe való beilleszkedésüknek megfelelően fonetikai vagy helyesírási és morfológiai különbségekben jelentkeznek.

$\mathrm{Az}$ tulajdonnévből keletkezett szavak és kifejezések jelentős része kapcsolatban áll a hagyománnyal, a történelemmel, az irodalommal, a Bibliával és a mitológiával. Ezek kutatása különösen izgalmas feladat, hiszen az egyes eponimák keletkezéséhez érdekes történetek füződnek, melyek megismerése általános kultúrtörténeti ismereteinket is szélesítheti. Az eponimák egyik típusa, a nemzeti mellett, az egyetemes kultúrát és civilizációt is tükrözi. Másik típusa pedig a különböző tudományágak szókincsének szerves részét alkotja, keletkezésük motivációja szintén érdekes kutatási területet jelent.

Tanulmányomban a magyar, a lengyel és a horvát nyelv eponimáinak fonológiai, morfológiai adaptációját és a helyesírást állítottam a középpontba, azt vizsgálva, hogy az idegen nyelvekben köznevesült szavak hogyan illeszkedtek be a vizsgált nyelvek rendszerébe.

\section{Fonológiai adaptáció}

\section{Az első csoportot alkotják azok a szavak, amelyek minden változtatás nélkül kerültek be mindhárom nyelvbe:}

m. amper, le. amper, horv. amper 'az áramerösség mértékegysége' (AndréMarie Ampère),

m. balboa, le. balboa, horv. balboa 'pénznem Panamában' (Vasco Núñez de Balboa),

m. bolivar, le. boliwar, horv. bolivar 'Venezuela pénzrendszerében a forintnak megfelelő pénzegység' (Simon Bolivar),

m. doberman, le. doberman, horv. doberman 'nagy termetü, rövid szőrü, hegyes fülü őrzö-védő kutyafajta' (Karl Friedrich Louis Dobermann),

m. dolomit, le. dolomit horv. dolomit 'kalcium- és magnézium karbonátból álló, mállékony kőzet' (Déodat de Dolomieu)

m. farad, le. farad, horv. farad 'az elektromos kapacitás egysége'(Michael Faraday),

m. fauna, le. fauna, horv. fauna 'egy meghatározott terület (vagy földtani korszak) állatvilága' (Fauna),

m. pantaleon, le. pantaleon, horv. pantaleon 'öt és fél oktáv hangterjedelmü, cimbalomra hasonlító hangszer'(Pantaleon Hebenstreit),

m. negus, le. negus, horv. negus 'melegített vörösborból készült ital, melyhez fahéjat, szegfüszeget és cukrot adnak' (Francis Negus). 
2. A második csoport szavai a magyarban és a lengyelben megőrizték az eredeti helyesírást, a horvátban a kiejtés szerinti írásmóddal találkozunk:

m. baskerville, le. baskerville, horv. baskervil 'talpas betükép'(John Baskerville),

m. biedermeier, le. biedermeier, horv. bidermajer 'a 19. század első felének kispolgári kedélyt, érzelmességet és családias hangulatot kifejező müvészeti, irodalmi és lakberendezési irányzata föleg a német nyelvterületen és a Habsburg Birodalomban' (Biedermann és Bummelmeier),

m. chateaubriand, le. chateaubriand, horv. šatobrijan 'angolosan sült dupla bélszínszelet sült burgonyával' (François René de Chateaubriand),

m. lutz, le. lutz, horv. luc 'ugrásfajta a mükorcsolyában' (Alois Lutz),

m. maxim, le. maxim, horv. maksim 'az első sikeres géppuska' (Sir Hiram Stevens Maxim),

m. zeppelin, le. zeppelin, horv. cepelin 'szivar alakú, merev vázú, kormányozható léghajó; a levegőnél könnyebb gázzal (hidrogén, hélium) töltik' (Ferdinand Zeppelin).

3. A harmadik csoportban találjuk azokat a szavakat, amelyek mindhárom nyelvben kiejtés szerint illeszkedtek be:

m. atlasz, le. atlas, horv. atlas 'térképalbum, térképfüzet, téma szerint összetartozó ábrák, rajzok elrendezett gyüjteménye, általában könyv alakban' (Atlas),

m. batiszt, le. batyst, horv. batist 'finom, sürü szövésủ len- vagy pamutvászon' (Baptiste de Chambray),

m. besamel, le. beszamel, horv. bešamel 'vajból, lisztből és tejből készül, tetszőlegesen füszerezhető alapmártás' (Louis de Béchamel),

m. bojkott le. bojkot, horv. bojkot 'jogi értelemben politikai, gazdasági vagy személyes kapcsolatok megszakítása állammal, szervezettel, személlyel megtorlás és valamilyen célú kényszerítés céljából; tudatos tartózkodás egyes árucikkek megvásárlásától a gyártó vagy a származó ország büntetéseként' (Charles Boycott),

m. ciceró, le. cycero, horv. cicero ' 12 pontos betünagyság' (Marcus Tullius Cicero),

m. dalmatika le. dalmatyka, horv. dalmatika 'liturgikus felsőruha a római egyházban' (Dalmácia),

m. huligán, le. chuligan, horv. huligan 'csirkefogó, vagány, garázda; bandázó fiatal' (Hooligan családnév),

m. írisz, le. irys, horv. iris 'nőszirom'( Írisz),

m. kondom, le. kondom, horv. kondom 'a nemi betegségektől védő és fogamzást gátló gumi óvszer férfiak számára’ (Condom nevü falu v. dr. Condom),

m. lincs, le. lincz, horv. linč 'felháborodott, megvadult tömeg önbíráskodása, bünös(nek vélt) személy meggyilkolása, agyonverése a tömeg által' (James Fitzstephen Lynch), 
m. nesztor, le. nestor, horv. nestor 'valamely testület legidősebb tagja, bölcs és megbecsült örege'(Nesztór, Homérosz: Iliász),

m. szendvics, le. sandwicz, horv. sendvič 'vajas kenyérszeletre vagy zsemlére helyezett kolbász, sajt, hús, hal stb. (esetleg beborítva más kenyérszelettel vagy félzsemlével)' (Lord John Montagu Sandwich),

m. szifilisz, le. syfilis, horv. sifilis 'bujakór, vérbaj, luesz, súlyos, fertőző nemi betegség' (Syphilis),

m. zsilett, le. żyletka, horv. žilet 'önborotva készülék, az ebbe való penge' (King Camp Gilette).

4. A negyedik csoportba kerültek azok a szavak, amelyek a magyarban megőrizték az eredeti írásmódot, a lengyelben és a horvátban pedig a kiejtés szerinti írás jellemző:

m. guillotine, le. gilotyna, horv. giljotina 'önborotva készülék, az ebbe való penge' (Joseph Ignace Guillotin),

m. havelock, le. hawelok, horv. havelok 'ujjatlan, könyökig érő gallérú régi férfiköpeny' (Sir Henry Havelock),

m. hertz, le. herc, horv. herc 'az elektromágneses rezgés frekvenciájának mértékegysége' (Heinrich Rudolf Hertz),

m. jacquard, le żakard, horv. žakart 'lyukkártya-vezérlésü, felsőmüves szövőgép bonyolult mintájú szövetek előállítására' (Joseph-Marie Jacquard),

$\mathrm{m}$. röntgen, le. rentgen, horv. rendgen, rentgen 'röntgensugárzás (Xsugárzás); a besugárzási dózis egysége' (Wilhelm Conrad Röntgen),

$m$. oersted, le. ersted, horv. ersted 'a mágneses térerösség korábbi mértékegysége a CGS rendszerben’ (Hans Kristian Oersted).

5. Ritkábban, de elöfordulnak olyan szavak is, amelyek az egyes nyelvekben két változatban fordulnak elö:

m. dzsörzé vagy jersey, le. dżersej vagy jersey 'kötszövött rugalmas ruhaanyag'(Jersey sziget),

horv. $d z ̌ u l$ vagy joule 'a munka és az energia alapegysége az SI rendszerben' (James Prescott Joule),

horv. brauning, browning 'öntöltő ismétlöpisztoly' (John Moses Browning).

\section{Morfológiai adaptáció}

Az azonos fogalmi körökbe tartozó szavak mindhárom nyelvben jellegzetes képzővel illeszkedtek be a nyelv rendszerébe.

1. A növénynevek a magyarban leggyakrabban -ia, ritkábban -a, a lengyelben -ja, -ia, illetve - $a$, a horvátban pedig -ija képzőt kapnak:

$\mathrm{m}$. begónia, le. begonia, horv. begonija 'trópusi eredetű, változatos levélrajzú virágos dísznövény’ (Michel Bégon),

m. dália, le. dalia, horv. dalija 'trópusi eredetü, változatos levélrajzú virágos dísznövény’ (Andreas Dahl), 
m. frézia, le. frezja, horv. frezija 'csipkevirág, tölcsér alakú, illatos virágokat hozó gumós növény’ (H. Th. Freese v. Elias Magnus Fries),

m. gardénia, le. gardenia, horv. gardenija 'fényes levelü, fehér virágú dísznövény’ (Alexandr Garden),

m. kamélia, kamelia, kamelija 'a teafélékhez tartozó, kelet-ázsiai eredetü, díszes virágú örökzöld cserje' (Georg Josef Kamel),

m. magnólia, le. magnolia, horv. magnolija 'liliomfa, tulipánfa, kora tavasszal nyíló, pompás fehér virágú, illatos keleti díszcserje’ (Pierre Magnol).

2. Az ásványnevekre a magyarban -it, lengyelben -it, -yt, a horvátban pedig -it képző a jellemző:

m. alexandrit, le. aleksandryt, horv. aleksandrit (II. Sándor, oroszul Alexandr),

m. gadolinit, le. gadolinit, horv. gadolinit (Johann Gadolin),

m. dunit, le. dunit, horv. dunit (Dun),

m. szamarszkit, le. samarskit, horv. samarskit (V. E. Szamarszkij-Bihovec).

3. A kémiai elemek nevei a magyarban szinte kivétel nélkül -ium végzödést kapnak, a lengyelben viszont csak maga a tulajdonnév van meg köznév formában, képző nélkül, a horvátban az -ij és ritkábban az -ium képzővel fordulnak elö:

m. einsteinium, le. einstein, horv. ajnštajnij, ajnštajnium, einsteinium 'a mesterséges transzurán elemek egyike' (Albert Einstein),

m. amerícium, le. ameryk, horv. americij 'mesterséges radioaktív elem a transzurán sorból' (Amerika),

m. berkélium, le. berkel, horv. berkelij 'mesterséges (transzurán) radioaktív elem, ezüstfehér, képlékeny fém' (Berkeley),

m. európium, le. europ, horv. europij 'a ritkaföldfémek csoportjába tartozó kémiai elem, szürke fém' (Európa),

m. gadolínium, le. gadolin, horv. gadolinij, gadolinijum 'ezüstfehér vegyi elem, a ritkaföldfémek csoportjából' (Johann Gadolin),

m. germánium, le. german, horv. germanij 'félvezető tulajdonságú szürkésfehér, rideg fémes elem' (Berkeley),

m. mendélevium, le. mendelew, horv. mendelevij 'mesterségesen elóállított radioaktív kémiai elem; a transzurán sorozat tagja' (Dmitrij Mengyelejev),

m. nobélium, le. nobel, horv. nobelij 'mesterségesen elöállított radioaktív elem a transzurán sorból' (Alfred Bernhard Nobel),

m. kürium, le. kiur, horv. kirij 'mesterséges radioaktív transzurán elem' (Marie és Pierre Curie),

m. holmium, le. holm, horv. holmij 'ritkaföldfém, kémiai elem' (Holmia, Stockholm latin neve),

m. kopernícium, le. kopernik, horv. kopernicij 'a legnehezebb transzaktinida' (Nikolausz Kopernikusz). 
4. A különböző fogalmi körökbe tartozó szavakat gyakran ugyanazon a képző segítségével alkotják, a leggyakoribb képző a magyarban a latinból származó -izmus, -ista, melynek lengyel megfelelői az -izm, -ista, a horvátban pedig az -izam, -ist képző.

$\mathrm{Az}$ általuk képzett szavak általában egy adott személyhez vagy a vele kapcsolatban álló fogalomhoz való kötődést, vele való összefüggést jelölik. Segítségükkel leggyakrabban filozófiai, vallási irányzatok, s egyéb társadalmi mozgalmak, illetve követőik nevei keletkeztek. Ennek kapcsán utalok arra, hogy az eponimák fonetikai és morfológiai adaptációjában ugyanaz az elv érvényesül, mint a klasszikus nyelvekből átvett jövevényszavaknál (a magyarba -izmus, a lengyelben -izm, a horvátban -izam).

Vallási irányzatok nevei:

m. arianizmus, le. arianizm, horv. arijanizam 'ókori eretnek keresztény szekta, amely Krisztust nem egylényegünek, csupán hasonló lényegünek hirdette az atyával' (Arius),

m. buddhizmus, le. buddyzm, horv. budizam 'Kelet-Ázsiában uralkodó vallás' (Buddha),

m. kálvinizmus, le. kalwinizm, horv. kalvinizam 'a protestantizmus Kálvin tanain alapuló változata' (Kálvin János).

A vallási irányzatok híveinek, követőinek nevét több képző segítségével alkotják, az egyik leggyakoribb a magyarban és a lengyelben is az -ista képzö, a lengyelben a szótári alak gyakran többes számban szerepel (-iści, -yści) végzödés, a horvátban - ist, -isti.

m. janzenista, le. jansenista, horv. jansenist '17. századi katolikus teológiai irányzat, amely Kálvinhoz közelálló tanokat képviselt’ (Cornelius Jansenius),

m. kálvinista, le. kalwinista, horv. kalvinist 'a protestantizmus Kálvin tanain alapuló változatának képviselője’ (Kálvin János),

m. donatista, le. donatyści, horv. donatisti '4. századi keresztény eretnekmozgalom hívei Észak-Afrikában’ (Donatus).

A másik jellegzetes szóalkotási mód ebben a csoportban a magyarban a -(i)ta t.sz. (-(i)ták), a lengyelben -(i)ta, t. sz. (-(i)ci), a horvátban -it, t. sz. -iti képzős szavak, melyek szótári alakja mind a magyarban, mind a lengyelben és a horvátban általában többes számú alakban szerepel:

m. adamiták, le. adamici, horv. adamiti '2-3. századi szekták tagjai' (Ádám),

m. jakobiták, le. jakobici, horv. jakobiti 'a Szíriában, Jordániában, Törökországban, Mezopotámiában, - melynek nagy része ma Irakhoz tartozik - és Indiában élő monofiziták' (II. Jakab),

m. maroniták, le. maronici, horv. maroniti 'a Földközi-tenger keleti medencéjének államaiban élő, az ortodox egyházból kivált, a római katolikus egyházhoz csatlakozott szír keresztények' (Maron).

Előfordulnak olyan példák is, ahol a magyarban a -(i)ta (-(i)ták), a lengyelben pedig az -anin (-anie) képző fordul elö, a horvátban pedig-ac, -ci. 
m. bazilita, le. bazylianie, horv. bazilijanci 'szerzetesrend a görögkeleti egyházban' (Nagy Szent Bazil).

A magyar az -us képzős szavaknak a lengyelben -anin (-anie) képző felel meg, a horvátban -ac, -ci:

m. dominikánus, le. dominikanie, horv. dominikanci 'Domonkos-rendi (katolikus) szerzetes' (Szent Domonkos),

m. fabiánus, le. fabianin, horv. fabijanac 'angliai reformer szocialista mozgalom a 19. század végén’ (Quintus Fabius Maximus),

m. franciskánus, le. franciszkanie, horv. franciskanac 'ferences rendi szerzetes' (Assisi Szent Ferenc),

m. szamaritánus, le. samarytanin, horv. samaritanac 'szigorúan törvénytisztelő zsidó szekta tagja' (Szamária).

Betegségek nevei:

A magyarban az -izmus és a lengyelben az -izm, a horvátban az -izam képzö jellemzö:

m. daltonizmus, le. daltonizm, horv. daltonizam 'a színtévesztés leggyakoribb fajtája; a vörös és a zöld szín megkülönböztetésére való képtelenség' (John Dalton),

m. narcisszizmus vagy narcizmus, le. narcyzm, horv. narcisizam 'önimádat, kóros önszeretet, valakinek önnön szépségében vagy erényeiben való tetszelgés' (Narcissus),

m. morfinizmus, le. morfinizm, horv. morfinizam 'morfium élvezete miatti kábítószer-függőség' (Morpheusz).

A különféle mozgalmak, politikai rendszerek, uralkodói formák elnevezéseiben is a fenti képző szerepel:

m. cezarizmus, le. cezaryzm, horv. cezarizam 'császári hatalom mint uralmi forma; a középkori császárság, tágabban a világi hatalom beleavatkozása a (katolikus) egyház ügyeibe' (Caius Julius Caesar),

m. sovinizmus, le. szowinizm, horv. šovinizam 'más népek elleni gyülöletet szító, a nemzeti felsőbbrendüséget hirdető szélsőséges nacionalizmus' (Nicolas Chauvin),

m. jakobinizmus, le. jakobinizm, horv. jakobinizam 'a jakobinusok radikális eszméivel és forradalmi terrorjával rokonszenvező, ezeket a gyakorlatba átültetni kívánó irányzat, mozgalom' (Saint Jacques).

\section{Összegzés}

Az eponimák száma mindhárom nyelvben meghaladja az ezret. Ebből a gazdag anyagból az adaptáció legfontosabb jellemzőit választottam ki bemutatásra.

Az eponimák a magyar, a lengyel és a horvát nyelv fonológiai és morfológiai rendszerébe nem mindig illeszkednek be azonos módon. A szavak az adaptáció során gyakran mindenféle változtatás nélkül kerülnek be mind- 
három nyelv rendszerébe, de számos példát találunk arra is, hogy a magyar nyelv megörzi az eredeti idegen írásmódot, míg a lengyelben és a horvátban a kiejtés szerinti írásmód jellemző. Szép számban találunk példát ennek ellenkezöjére is, amikor a magyarban a szavakat a kiejtés szerinti helyesírással írjuk, a lengyel és a horvát viszont megőrzi az eredeti idegen nyelvi formát.

A szavak egy része mind a magyar, mind a lengyel, mind a horvát nyelvben változásokon megy keresztül, a helyesírás a magyar, a lengyel, illetve a horvát kiejtést tükrözi, s néhány esetben egy szó két változatban is elöfordulhat, az egyik forma a kiejtést, a másik pedig az eredeti helyesírást tükrözi. Az adaptáció ilyen módja a jövevényszavakat is jellemzi.

A közszóvá válás során a tulajdonnevek gyakran kaphat különbözö képzőket, melyek gyakran egy-egy szócsoport jellemzőjévé válhatnak, pl. növénynevek, ásványnevek, kémiai elemek, vallási irányzatok, betegségek, politikai mozgalmak, stb. nevei.

\section{Irodalom}

BAKOS 1973 = BAKOS F. (szerk.) Idegen szavak és kifejezések szótára. Budapest, 1973.

BEECHING 1983 = BEECHING C. L. A Dictionary of Eponyms. Oxford - New York, 1983.

GECSE 1973 = GECSE G. Vallástörténeti kislexikon. Budapest, 1973.

HEGEDÜS $2000=$ HEGEDÜS A. A tulajdonnév $\rightarrow$ közszó váltásról // Magyar nyelvjárások, A Debreceni Egyetem magyar nyelvtudományi tanszékének évkönyve, №XXXVIII. Debrecen, 2000. 175-178.

KOPALIŃSKI 1999 = KOPALIŃSKI W. (szerk.) Podręczny słownik wyrazów obcych. Warszawa, 1999.

KOPALIŃSKI $2004=$ KOPALIŃSKI W. (szerk.) Słownik eponimów czyli wyrazów odimiennych. Warszawa, 2004.

MRŠIĆ $2000=$ MRŠIĆ D. Eponimski leksikon. Zagreb, 2000.

SZYMCZAK 1967-1976 = SZYMCZAK M. (redaktor naukowy) Słownik języka polskiego 1-3. Warszawa. 1994.

BENKÖ 1967-1976 = BENKÖ L. (föszerk.) A magyar nyelv történeti-etimológiai szótára 1-3. Budapest, 1967-1976.

TOLCSVAI NAGY 2007 = TOLCSVAI NAGY G. (szerk.) Idegen szavak szótára. Budapest, 2007.

TÓTFALUSI 2004 = TÓTFALUSI I. Idegenszó-tár. Idegen szavak értelmezö és etimológiai szótára. Budapest, 2004. 